\title{
THE PLACE OF WOMEN IN THE MODERN NATIONAL MOVE- MENTS OF THE EAST
}

\author{
By Miss AGNES DE SÉLinCOURT
}

"You know," said an old Mohammedan Sheikh as he somewhat timorously contemplated the prospect of modern education for his little girl, "you know, we do not care to have our daughters stay in school very long." " $\mathrm{Oh}$, but all that is past," broke in a young Moslem B.A., who had ventured within the Mission precincts on a similar errand; " our country can never be great until our women are properly taught."

So the old and the new are meeting to-day in the East; the clash of conflicting theories as to woman's rightful place in the life of a nation is one of the forces which is shaking society to its foundations. Not in one country alone is this phenomenon observable; wherever the East is being touched with the breath of awakening life, the woman's question leaps into prominence.

With the proclamation of the Constitution in Turkey in August 1908, thousands of women threw off their veils and streamed into the streets with their husbands to join in the general shout of "Liberty." Though this proved to be a premature attempt and the women have since been forced back into their former seclusion, yet below the surface the ferment continues unabated, and it cannot be long before the social life of Turkey is transformed. The last few years have seen the birth of a national consciousness in Persia, and with it there also an awakening has begun among the women. In one town alone a hundred schools for girls have been opened within a year; in one of the largest a mother was found sitting in the same class with her two daughters, the youngest a child of seven. In China, also, schools for girls are springing up like mushrooms in almost every province, and though, owing to the lack of qualified teachers, much of the work that is being done is almost comically crude, yet 
the pathos of these women's eagerness turns laughter into something nearer tears.

In India, of which I wish principally to speak, side by side with the growth of national ideals and aspirations, the woman's question grows steadily in importance. In a district of Eastern Bengal with a population of $\mathbf{8 5 0 , 0 0 0}$ where, six years ago, there were four girls' schools, to-day there are 300. From the Government Quinquennial Review of Education in India (1902-7) we find that while the chief increase in female education has taken place in Bengal and Eastern Bengal and Assam, yet there is no province in which there has not been advance during the past quinquennium. Of the United Provinces, which is the most backward part of India in the matter of female education, the Report runs as follows: "It is true that the vast mass of the people are as indifferent, apathetic, and perhaps as prejudiced as ever, nevertheless the outstanding fact remains that the percentage of girls attending school to the female population of school-going age has very nearly doubled. It is satisfactory also to find that the increase has been general throughout the Province."

Not only in the quickly increasing percentage of girls attending school do we find traces of the new spirit, but in every department of social life. Clubs are being started, women's periodicals launched, philanthropic activities undertaken, all carried on by Indian women for Indian women. One of the most significant movements of the kind is the Bharat Stri Mahamandal, a Society formed in the United Provinces last winter by some advanced Hindu and Moslem women in the Empire. The following extracts are from the inaugural address given at the meeting of the Mahamandal: " "The hand that rocks the cradle rules the world.' It is to make ourselves worthy and efficient rulers, to equip ourselves with the fitting of sound rulers, to have our Indian social world better governed, that the Bharat Stri Mahamandal has been founded. No nation can rise above the spirit of its women. If that spirit be asleep the nation can never be wide awake. Thus the Bharat Stri Mahamandal is to form a common centre for all women thinkers and women workers of every race, creed, class, and party in India, to associate themselves together for the progress of humanity. The secretaries and members of the executive body are always to be chosen from the Hindu (including Sikh, Jain, etc.), Mussulman, Buddhist, and Parsi women of India. A certain number of 'helpers' are to be selected from the AngloIndian and Christian members who join the Mahamandal. Their 
function will be to help the executive body by suggestions and ideas which are expected to be stored up in them by their greater experience in these lines of work, also to co-operate with us in any other way found practicable."

Those who know something of social conditions in the East even ten years ago will realize the swiftness and the significance of the appearance of these phenomena; one cannot but feel a measure of sympathy with the alarm and hesitancy of the old Sheikh and his confrères, as they watch the old order changing, and wonder whereunto this will grow. Times of transition are always difficult, and the changes which we see taking place in the thoughts and ideals and opportunities of Eastern women are such as cannot but give food for serious reflection. And yet the dangers of advance can only be met by still further advance, and surely there are none who care for the progress of humanity, whose hearts do not throb in sympathy with these women, struggling, sometimes crudely, often mistakenly and yet passionately and sincerely, for light and knowledge and liberty. Who would not respond to the appeal lately voiced by a Hindu lady before a Western audience : "It is clear that our advance as Indian women must be based on our national literature, cur national history, our national ideals. In working out its steps, we need sympathy, we need the fellowship of all the noble women of the world"?

Christian missionaries have played a larger part than any other body in bringing about this awakening. During the greater part of the nineteenth century they stood well-nigh alone in the East in their championship of the woman's cause ; with the result that until quite recent years it was practically only in the Christian Church that women of culture and education were to be found, and even yet the vast majority of the women leaders in the East are Christian. But a realization of the necessity for an educated and emancipated womanhood is now no longer confined to those sections of the community which are directly influenced by Christianity, but is laying hold of Eastern nations as a whole. The times are moving and we must move with them, if we would enable the Christian women of the East to preserve, and yet further to strengthen, their present position of leadership. We have inherited a noble trust through the toil and devotion of missionaries in the past; but changing conditions necessitate readjustments, and can it be doubted that those great pioneers of women's work in the East who, fifty 
years ago, thought out and laid down the lines which have been followed in the main by their successors ever since, would be the first to desire that their policy should be revised and adapted so far as may be to the actual needs of the situation to-day? If the Christian Church is to make any adequate attempt to meet the present need of the non-Christian world, it would seem to be imperative that she devote some of her best thinking to the solution of the problems which are involved in the following questions: What is the message of Christianity to the awakening womanhood of the East? How may that message be most wisely and effectively delivered ?

I. What is the message of Christianity to the modern woman ?

The phrase " modern woman" is not so incongruous in connection with the East as may at first sight appear, for in the matter of women's problems, as in other directions, the leaders of Eastern nations are at the present time assimilating Western ideas with startling rapidity, and the woman's question, like so many other social questions, is becoming every day more and more obviously related in the East and the West. Some whose main interest lies in the work of the Christian Church abroad have perhaps hardly realized the quiet revolution which has taken place in England during the last half-century in the position of women, and the manifold problems which are arising as a result of it. ${ }^{1}$ But modern missionary work needs to be reviewed in close relation to these problems, even as they need to be thought out in the light cast upon them by the work of the missionary abroad, and both in the light of a careful survey of the causes and effects of woman's progress or retrogression from the beginnings of history up to the present time, and the bearing of her evolution upon the life of nations.

One fruitful line of study, for example, would be that of the position of women in medieval times, as compared with their position after the Reformation. The conventual ideal made possible for women a career greater in many respects than any other which has been thrown open to them in the whole course of modern European history, and found its fullest exemplification in such women as St. Hilda of Whitby, or the Abbess of Las Huelgas in Spain. In postReformation days, on the other hand, in the reaction from the evils of the monastic system supreme stress was laid upon the sanctity

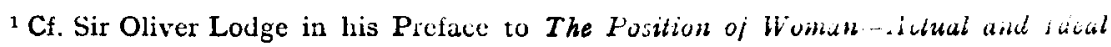
Nisbet \& Co.
} 
of the home, with the result, among other and nobler ones, that for generations marriage became woman's only recognized vocation. A careful study of Eastern history along similar lines is also essential ; we must not allow the present backward condition of women in the East to blind us to the fact that it numbers among its great ones in the past women such as Rani Devi, the wife of the Emperor Asoka, and Lilavati, daughter and disciple of the famous mathematician, Bhashkaracharya. The East has much to teach us of the glory of motherhood, despite the fact that over-emphasis of that one side, great though it be, of woman's life is largely responsible for the degradation of widows and childless wives, and other social evils which enlightened Indians deplore as sincerely as we do. Ancient Indian poetry reaches its highest level in its portraiture of such exquisite woman characters as Sita, Damayanti, or Sakuntala.

Whatever be the message we would take to the East, it must at least be great enough to include all that is true in every past conception of woman and in every aspiration that is stirring among women to-day. A great part of the present difficulty lies in the fact that neither woman's capabilities nor her limitations are known as yet, nor can they be fully known until she has had opportunity to find herself. Then, and not till then, temperamental characteristics will tell, and there will be a clearing up of the present confusion between accidental and essential difference. Meanwhile there is a spirit of unrest among women all the world over, a reaching out after a freer, fuller life ; and it must never be forgotten that a free, full life for women is an integral part of the reign of God upon earth, which our Lord came to establish. The messengers of the Cross must accept and encourage the highest aspirations of women, seeking the solution of confusing and apparently contradictory elements in the light of the fundamental teaching of Christ that life comes through death, self-realization through self-sacrifice. It is comparatively easy to push to an extreme, but the perfect and more difficult way is to bring both extremes to a golden mean, to combine freedom with self-imposed restrictions, and enthusiasm with sanity. One main justification for the missionary enterprise lies in the conviction that Christianity alone, among all the religicns and philosophies of the world, holds the key to the right solution of the relations between men and women. But our presentation of Jesus Christ in this as in every direction must be made in a spirit of deep humility, realizing how far short we in the West still fall of His teaching and His life, and 
how only as the East brings in its contribution can we rise to a perfected humanity in Him.

II. How at this time may our message be most wisely and effectively given ?

There seems little doubt that our main opportunity at the present moment lies along the line of education; it is in this more than in any other direction that the East is looking to us for help. The education of women in India, for example, has now reached a point not dissimilar from the crisis which confronted that of men some fifty years ago when Dr. Duff's epoch-making work was done. Whether we will or no, upon us Westerners must rest very largely the responsibility of determining the lines along which the education of the rising generation of Eastern women shall be carried out. The next ten years will see the beginnings of many things in the women's educational world in the East. Few things could be more fatal at this juncture than a hasty and wholesale adoption of existing Western methods. The need of the present crisis can only be fully met as those in the front rank of education in the West, in consultation with the finest leaders of Eastern thought, plan out some system of education which shall be true to the genius of the East, and in which a due place shall be given to those other elements in education, such as manual, industrial, and domestic training, which are necessary, besides the purely intellectual, for balance of character and a sane outlook upon life.

Upon us also rests the solemn responsibility of determining whether this education shall be imbued with a partly materialistic. partly agnostic spirit, or with the spirit of Christ.

The time seems therefore to have come when we ought seriously to consider whether, in view of the present situation in the East, educational work should not be given the central place in our programme of missionary work among women, and this not to the neglect of other most important activities, but rather to the strengthening of them all through a closer co-ordination of the whole.

Indeed, the call of the present educational opportunity seems to demand a threefold co-ordination of the missionary force.

(1) In the first place, there is need of closer co-ordination of the various branches of missionary work.

In such a co-ordinated scheme medical work, for example, would be regarded as a preparation for educational work, and evangelistic work as its essential supplement. The testimony of Dr. Emmeline 
Stuart, who has been working for the last fourteen years as a medical missionary in Persia, is of value here. She writes: "Our medical missions have removed prejudices and opened doors on every side for educational missionaries, but these do not come! Of what use are medical missions, if educational missions do not follow in their wake? We want to see high-class schools established in each of the chief towns of Persia; each school with an educational missionary at its head, and a band of trained teachers to co-operate. Unless this can be done, and that soon, our day of opportunity will have passed in Persia ; our medical missions, successful though they may have been in their own line, will have failed in their ultimate and highest purpose." 1

This is a truly typical situation. In many other parts of the East we find that medical missions which have done magnificent work are failing to reap their highest results because they are not being followed up by adequate educational work.

Similarly, as our educational work develops, it is essential that it be ever more and more closely co-ordinated with the evangelistic work of the missionary force. We have seen in the past, more especially in educational work among boys and young men, how the pressure of examination and of constantly growing curricula has tended to crowd out individual evangelistic effort; let us be warned in time in any new schools that we may start. Not only must we endeavour to secure that they are adequately staffed, but we must bring them into the closest possible touch with whatever evangelistic work is going on in the same district, enlisting, wherever practicable, zanana or village workers to visit the homes of the pupils and to help us in every possible way in our endeavour to bring our pupils, and not our pupils only, but their parents also and friends, into personal and vital relationship with Jesus Christ.

(2) A second need is closer co-ordination of the work of the various missionary societies.

It was well said at the World Missionary Conference that in many cases closer co-operation would be equivalent to a doubling of the missionary staff. This applies especially to educational work among women, on account of the small numbers of women and girls at present receiving Christian education, and the fact that far too large a proportion of missionaries are giving their time to teaching them in small and scattered classes. If the missionary societies

\footnotetext{
${ }_{1}$ Daylight in the Hayem. Oliphant, Anderson \& Ferrier.
} 
could see their way to substituting for these, wherever possible, union training schools and colleges, the work would be more efficiently done, and a considerable number of educationists would be set free for pioneer work in connection with up-to-date schools for non-Christian girls, so urgently needed at the present time. No scheme of co-operation is possible without a certain amount of individual sacrifice; we need a largeness of vision to see things in their true proportions, and a burning enthusiasm for the Kingdom of God, which will not allow local and temporary inconvenience to block the way when the call comes to advance.

(3) A third claim is closer co-ordination between men's and women's work.

Much might be gained if the method of some missionary societies were adopted by all, and the work of missions, both at the home base and on the field, were carried on by joint-committees of men and women, with sub-committees of men and women separately, when so desired, to deal with especial subjects.

The gains on the women's side would be many and obviouswomen's work as a whole is not as yet so well organized and disciplined on the mission field as is that of men; it stands in very special need of just that organizing and co-ordinating which such committees might make possible. On the other hand, the women's contribution to the common stock of experience would not prove altogether valueless.

In the East men are of necessity a good deal more in evidence than women; it is sometimes perhaps difficult for the leaders of missionary policy to bear in mind that women are anything more than a small and practically negligible section of the community; and so it too often happens that while a generous tribute is paid to women's work, little serious thought is given to its problems. And yet all the time the inverse of the scene in the Interpreter's House is being enacted; the missionary, in his college or school, spends himself in the endeavour to quench the fire of opposition to the clains of Christ or adherence to caste law, and wonders at his small success, forgetting that all the while the flame is being fed by the persistent, well-nigh omnipotent, influence of the unseen wife or mother. Not until men and women missionaries unite, far more than is as yet customary, in simultaneous and concentrated attack, can we hope to see anything like victory.

At present in India, for example, we find not infrequently whole districts in which there are only women missionaries, and again 
other districts in which only men are working, and the result is a terrible hindering of the progress of the gospel. Even when men and women missionaries are working in the same town, they are very often reaching, or seeking to reach, entirely different families.

Educational work among Christians has in various parts of the mission field suffered not a little in the past from a similar lack of co-ordination. In one district the girls would be receiving a higher education than was being provided for the boys, in another district the reverse would be the case ; in neither instance has the discrepancy made for the happiness and usefulness of the community as a whole.

Much of the success of the present forward move in the direction of education for non-Christian girls must depend upon the closeness of its co-ordination with similar work that is being carried on for boys and young men. "Schools for non-Christian girls should be opened, whenever possible, as 'twins' to existing boys' high schools. This would give a nucleus to start with among the sisters of the boys, an area for recruiting, a permanent connection, a splendid point d'appui, and an unparalleled opportunity for co-ordination and concentration. . . . The divorce of men's and women's work leads to much, very much leakage of force, and often to heartrending separations in the families of converts." 1

An idea seems to be gaining ground in some quarters that the day of mission schools for non-Christian girls in the East is over, and that the only schools which have a future are those upon a secular basis. But while mission colleges and schools for men and boys retain their present popularity, it is surely reasonable to hope that there is a place for schools for girls along similar lines, and that if these schools can be brought up to a standard of efficiency equal to that of the boys' schools, they will be equally appreciated and desired. It is not the missionary, but the amateur element in education which spells disaster. Missionary educational work for nonChristians on the men's side is of long standing in the East ; among women it is in its infancy-those engaged in it are treading a new and untried path, and greatly need the strength that would come from close co-operation with those possessed of a longer and wider experience.

A larger place also might well be given to women on the various missionary literature committees, that the growing need for suitable literature for women and girls may be kept constantly to the front.

${ }^{1}$ Young India and the Education of Girls. By E. R. M'Neile. Church Missionary Society, Salisbury Square, London, E.C. 
With the memories of the World Missionary Conference fresh in our minds, the advantages of co-operation need no advocate; possibly in no other department of missionary work is co-operation more imperatively needed than in work for women in the East, both on account of the extreme complexity and delicacy of the problems to be handled, and also of the lewness of the workers as compared with the vastness of the work to be done. It is a happy augury that just now, when our need for mutual help and counsel is so great, this International Review should come into being - a meeting-ground where we may learn more and more to understand and appreciate thoroughly one another's methods and ideals. Within the limits of the present article it has been possible merely to touch in the barest outline upon the place of women in the modern national movements of the East, and to indicate some of the problems arising therefrom; it must be left to future contributors to take up various aspects of this great question in that detail which any adequate treatment of them would necessitate. An attempt has been made here simply to draw attention to the movement for the education and emancipation of women as being one of the biggest factors in the present situation in the East-one which cannot but be productive of profound and far-reaching results, for good or for evil, upon the history not of one nation only, but of the whole human race, and to point out that this world-wide movement among women constitutes a peculiarly urgent call to the Christian Church of to-day-a call to think out anew what message Christianity has for the twentiethcentury woman, what light and leading it can give her in her struggle towards self-realization; a call to consider, also, how that message may be so delivered as to bring about its acceptance and to secure thereby the building up of a redeemed society upon the only true foundation-allegiance to Jesus Christ our Lord.

Such a task is surely worthy of a place in the thought and sympathy of leaders in the Church of Christ in every land. May there be many whom God shall call to give not thought and sympathy merely, but their lives, lived out in the East, in unreserved abandonment to this great and glorious cause. 